\author{
Roman BABKO ${ }^{1}$, Tatiana KUZMINA ${ }^{2}$, Katarzyna JAROMIN-GLEN' ${ }^{3 *}$ \\ and Andrzej BIEGANOWSKI ${ }^{3}$
}

\title{
BIOINDICATION ASSESSMENT OF ACTIVATED SLUDGE ADAPTATION IN A LAB-SCALE EXPERIMENT
}

\author{
BIOINDYKACYJNA OCENA ADAPTACJI OSADU CZYNNEGO \\ W WARUNKACH EKSPERYMENTU LABORATORYJNEGO
}

\begin{abstract}
The adaptation of activated sludge from the Hajdow sewage treatment plant in a laboratory SBR was studied. The structure of the ciliate assembly was considered as a criterion. 32 ciliate species were found during the experiment. The composition and changes in the ciliate community structure during the process of activated sludge adaptation was examined. In the process of adaptation, reduction was observed in the number of ciliate species together with an increase in assembly total abundance. The decrease in the Shannon diversity index and equitability index in the adaptation process was observed. In the process of adaptation, two states of ciliate assembly were marked out - unstable transient period and stable period. During the transient period, reduction of ammonium utilization efficiency down to $50 \%$ and its subsequent increase up to $80 \%$ in the stable period were observed. In the transient period, the Simpson dominance index remained low but increased in the stable period. At a temperature of $10^{\circ} \mathrm{C}$, the transient period lasted from six to nine days. After the stabilization process, the diversity of the ciliate assemblage remained at a lower level. Rarefaction methods showed that the number of potential ecological niches of ciliate amounted to 30 in the adaptation period, whereas there were only 15-20 ecological niches in adapted sludge.
\end{abstract}

Keywords: bioindication, activated sludge, ciliates community, biocenotic indices, adaptation, SBR-type bioreactor, lab-scale experiment

\section{Introduction}

Wastewater treatment is a constantly modified and improved process that requires scientific research. Most of such investigations are performed in a laboratory environment using appropriate equipment [1-4]. When activated sludge is transferred to a different environment, its community undergoes a period of intense transition needed for adaptation [5]. Activated sludge for laboratory is often taken from large-scale wastewater treatment plants (WWTP). A majority of papers published on this subject deal with activated sludge adaptation to the influence of various toxic substances. In a number of papers, the aspects of

\footnotetext{
${ }^{1}$ I.I. Schmalhausen Institute of Zoology of National Academy of Sciences of Ukraine, B. Khmelnitsky 15 , 01601 Kiev, Ukraine, email: rbabko@ukr.net

${ }^{2}$ Sumy State University, N. Rimsky-Korsakov 2, 40007 Sumy, Ukraine, email: kuzmina_tm@ukr.net

${ }^{3}$ Institute of Agrophysics, Polish Academy of Sciences, ul. Doświadczalna 4, 20-290 Lublin, Poland

*Corresponding author: k.jaromin-glen@ipan.lublin.pl
} 
adaptation of activated sludge microorganisms to the effect of phenol [6, 7], high concentrations of ammonium [8], organic solids accumulated in the system [9], toxic organic micro-pollutants [10], bisphenol-A [11] and other [12-16] are examined. In the work of Bajenov and Kanunnikova [17], adaptation of activated sludge to low oxygen concentrations was also studied. A detailed account of the process of activated sludge adaptation is provided in the work of Anielak and Piaskowski [18]. Setting of adaptation regimes and periods makes it possible to conduct the research without considering the reaction of activated sludge to stress caused by repeated volume reductions and stabilization of the main factors. To avoid mistakes in the experimental results, it is important to assess quantitatively in advance whether conditions in the activated sludge have stabilized [19, 20]. The common practice assumes that the optimal period for adaptation lasts 2-2.5 sludge ages [21-23]. However, a body of evidence proves an assumption that the period of adaptation should last for 9 weeks [24]. However, in each case, the time and quality of adaptation may depend on the primary state of activated sludge, season, and the other factors $[25,26]$. This necessitates searching for criteria that facilitate controlling the adaptation process $[27,28]$. In this respect, it is interesting to use the fully automated image analysis procedure for characterization of the activated sludge composition [29, 30]. The aim of this work is to study the transformations of the most representative and diverse group of prokaryotes (ciliates) in the process of activated sludge adaptation to the conditions of the laboratory SBR.

\section{Materials and methods}

The experiment was carried out in a SBR-type laboratory reactor with autonomous control of oxygen supply and recording of its concentration, as well as automatic recording of $\mathrm{pH}$ and redox potential. The laboratory SBR consists of three chambers with a volume of $2 \mathrm{dm}^{3}$ each; in addition, the temperature was stabilized at $10^{\circ} \mathrm{C}$ using a water jacket. The mixing and aeration systems are provided centrally, individually for each chamber.

The SBR reactor had the following modes of operation. The cycle of the reactor lasted 12 hours, the operating cycle consisted of six successive phases: I - fill (10 minutes), II - mix (180 minutes), III - react (420 minutes), IV - settle (90 minutes), V - decant (10 minutes), and VI - idle (10 minutes). The mixture in the chamber comprised activated sludge $-0.6 \mathrm{dm}^{3}$, raw sewage $-0.5 \mathrm{dm}^{3}$, and purified wastewater $-0.7 \mathrm{dm}^{3}$. Each time of decantation (end of cycle) pumped out $0.5 \mathrm{dm}^{3}$ of purified wastewaters; at the same time, raw sewage was pumped into the chamber during the filling phase (at the beginning of the next cycle).

$\mathrm{N}-\mathrm{NH}_{3}$ and TSS (Total Suspended Solids) were measured using a HACH DR 3600 spectrophotometer from HACH-Lange. The analysis was based on the methodology developed by HACH-Lange. The turbidity was measured using nephelometry CyberScan TN-100 EUTECH Instruments. The measurement of contamination was performed immediately after the idle phase.

The activated sludge and sewage from the Hajdow wastewater treatment plant (Lublin, Poland), sampled within winter period at temperature $10^{\circ} \mathrm{C}$, was used as material for this study.

The studies were carried out with an Olympus CX41 microscope. The ciliates were identified in vivo. For diagnosis, the method of Galliano was used. The nuclear apparatus of the ciliates was stained with methylene green. 
The ciliates were counted in a volume of $25 \mathrm{~mm}^{3}$ (microsamples). The calculation was performed in five replicates. The data were averaged and recalculated to $1 \mathrm{~cm}^{3}$. Data for colonial protozoa are presented as the number of zooids in $1 \mathrm{~cm}^{3}$.

Ciliate species richness in the different cycles was compared using rarefaction curves. Hierarchical cluster analyses based on the Euclidean similarity index (dendrogram) were used to compare the species assemblages at the different cycles [31]. These analyses (rarefaction curves, cluster analysis) were performed using the software program Past 1.57 [32].

Species richness $(S)$, Shannon-Weaver index of diversity $(H)$, equitability $(j=$ evenness) $(j=H / \ln S)$, and Simpson dominance index were used to compare ciliate assemblages between the cycles [33-37].

Canonical correspondence analyses (CCA) was carried out based on ciliate abundance. Multivariate analysis was performed using the software program Past 1.57 [32].

\section{Results and discussion}

The sludge was sampled at the final stage of purification, when factorial fluctuations in the environment are minimal. The stability conditions at the final stage of purification presuppose the existence of an unstressed community of activated sludge. The community of activated sludge ciliates was analyzed. Their structure was considered as the initial structure. The composition of the assemblage of ciliates and the dynamics of their abundance during the experiment are shown in Table 1.

The important measure of the quality of sewage treatment is a effectiveness of reduction ammonium [38-41]. From the beginning of the experiment, the treatment efficiency of wastewater added to the SBR was monitored by the reduction of $\mathrm{N}^{-\mathrm{NH}_{3}}$. The dynamics of changes in ammonium utilization efficiency can be well described with a polynomial equation with a high value of the approximation coefficient $-R^{2}$ (Fig. 1 ). The efficiency of nitrogen utilization was calculated based on its content at the beginning of the cycle after adding and mixing of wastewater with an activated sludge and content of nitrogen at the end of the cycle in supernatant after sedimentation.

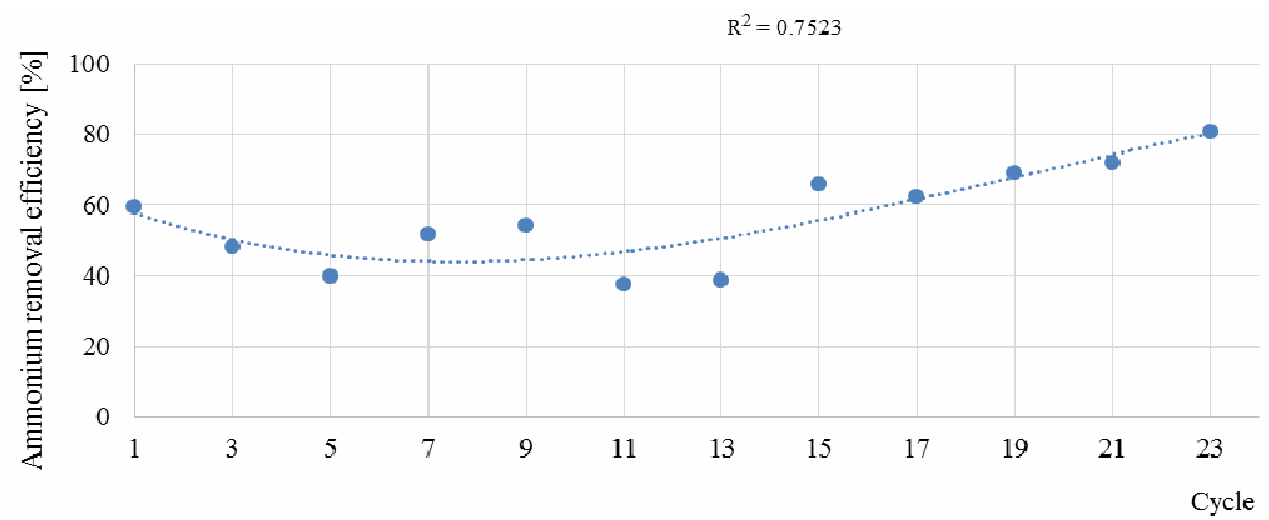

Fig. 1. Ammonium removal efficiency in the process of adaptation of the activated sludge in the SBR 
Comparison of efficiency values of the analyzed system

\begin{tabular}{|c|c|c|c|c|c|c|}
\hline \multirow[b]{2}{*}{ Species } & \multicolumn{2}{|c|}{ Hajdow WWTP } & \multicolumn{2}{|c|}{ Transient period } & \multicolumn{2}{|c|}{ Adapted period } \\
\hline & $\mathbf{X}^{*}$ & \begin{tabular}{|l|} 
\\
$\mathbf{S} * *$ \\
\end{tabular} & $\mathbf{X} *$ & $\mathbf{S} * *$ & $\mathbf{X}^{*}$ & $\mathbf{S} * *$ \\
\hline Acineria incurvata (Dujardin, 1841) & 190.21 & 63.25 & 26.8 & 13.5 & 20.4 & 7.9 \\
\hline Acineria uncinata (Tucolesco, 1962) & 371.69 & 88.2 & 294.0 & 78.0 & 1061.0 & 236.1 \\
\hline Acineta fluviatilis (Stokes, 1885) & 34.12 & 14.2 & 6.1 & 6.1 & - & - \\
\hline Apoamphileptus claparedii (Stein, 1867) & 40.25 & 12.3 & - & - & - & - \\
\hline Apsiktrata gracilis (Penard, 1922) & 40.25 & 24.24 & 224.9 & 43.2 & 0.7 & 1.1 \\
\hline Aspidisca cicada (Müller, 1786) & 410.78 & \begin{tabular}{|l|}
375.069 \\
\end{tabular} & 919.5 & 84.3 & 1410.0 & 35.9 \\
\hline Aspidisca lynceus (Müller, 1773) & 100.23 & 23.094 & 102.2 & 33.3 & 37.3 & 40.4 \\
\hline Carchesium polypinum (Linnaeus, 1758) & 142.29 & 51.36 & 134.3 & 29.1 & 136.0 & 34.8 \\
\hline Cinetochilum margaritaceum (Ehrenberg, 1831) & 94.25 & 23.094 & 29.7 & 20.8 & 46.4 & 30.0 \\
\hline Crossacineta ornata $($ Sand, 1899) & 20.13 & 15.3 & 26.6 & 11.1 & 13.3 & 8.5 \\
\hline Epistylis coronata (Nusch, 1970) & 350.98 & 69.24 & 114.7 & 66.3 & 28.9 & 38.6 \\
\hline Epistylis plicatilis (Ehrenberg, 1831) & 100.23 & 39.21 & 5.8 & 7.8 & - & - \\
\hline Euplotopsis affinis (Dujardin, 1841) & - & - & 3.0 & 3.0 & 6.7 & 1.6 \\
\hline Holophrya discolor (Ehrenberg, 1834) & 53.23 & 29.36 & 1.1 & 1.8 & 217.2 & 37.2 \\
\hline Litonotus fusidens (Kahl, 1926) & - & - & 5.9 & 4.0 & - & - \\
\hline Litonotus lamella (Müller, 1773) & 65.64 & 25.36 & 62.9 & 19.7 & 78.1 & 44.0 \\
\hline Metacystis sp. & 13.11 & 11 & 39.8 & 8.2 & - & - \\
\hline Opercularia articulata (Goldfuss, 1820) & - & - & - & - & 2.2 & 3.6 \\
\hline Opercularia coarctata (Claparède \& Lachmann, 1858) & - & - & 5.3 & 8.9 & - & - \\
\hline Opercularia microdiscus (Faure-Fremiet, 1904) & 40.25 & 31.1 & 8.3 & 13.9 & - & - \\
\hline Plagiocampa rouxi $($ Kahl, 1926$)$ & 53.23 & 27.69 & 5.5 & 5.5 & 34.1 & 13.3 \\
\hline Pseudovorticella elongata (Fromentel, 1876) & 205.5 & 147.5 & 151.5 & 50.4 & 23.3 & 17.2 \\
\hline Thigmogaster potamophilus (Foissner, 1988) & 360.87 & 278.3 & 131.3 & 49.9 & 5.3 & 5.3 \\
\hline Thuricola kellicottiana (Stokes, 1887) & 40.25 & 12.8 & 16.4 & 6.5 & 7.3 & 10.9 \\
\hline Tokophrya lemnarum $($ Stein, 1859) & 20.13 & 12.3 & 17.8 & 4.7 & 28.9 & 15.7 \\
\hline Tokophrya quadripartita (Claparède \& Lachmann, 1859) & 20.13 & 19.1 & 8.7 & 2.9 & 8.7 & 2.9 \\
\hline Urotricha farcta (Claparède, Lachmann, 1859) & 20.13 & 18.3 & 23.3 & 4.3 & - & - \\
\hline Vorticella aquadulcis-complex & 100.23 & 29.33 & 89.4 & 58.3 & 34.5 & 30.2 \\
\hline Vorticella convallaria-complex & - & - & 13.1 & 17.4 & 6.9 & 9.2 \\
\hline Vorticella microscopica (Fromentel, 1874) & 90.78 & 24.3 & 4.8 & 8.1 & - & - \\
\hline Vorticella microstoma-complex & 20.13 & 13.2 & 28.9 & 12.9 & 11.7 & 12.8 \\
\hline Vorticella octava-complex & 63.33 & 36.14 & 43.3 & 23.9 & 1.1 & 1.8 \\
\hline
\end{tabular}

* - average, ** - standard deviation

During the first eleven cycles, the efficiency of $\mathrm{N}^{-\mathrm{NH}_{3}}$ utilization remained around the level of $50 \%$ (Fig. 1). Starting from the thirteenth cycle, the efficiency grew to $70-80 \%$, which corresponds to good, stable work of SBR.

Concerning suspended matters, the efficiency of reduction thereof after the first cycle reached $97-99 \%$ and stabilized at this level (Fig. 2).

The fact that the efficiency of purification in the process of adaptation remained stably high can be explained with as follows: suspended matters mainly consist of bacteria; removal thereof is the function of ciliates and rotifers, and their quantity in the SBR remained high or was increasing until the end of experiment. 


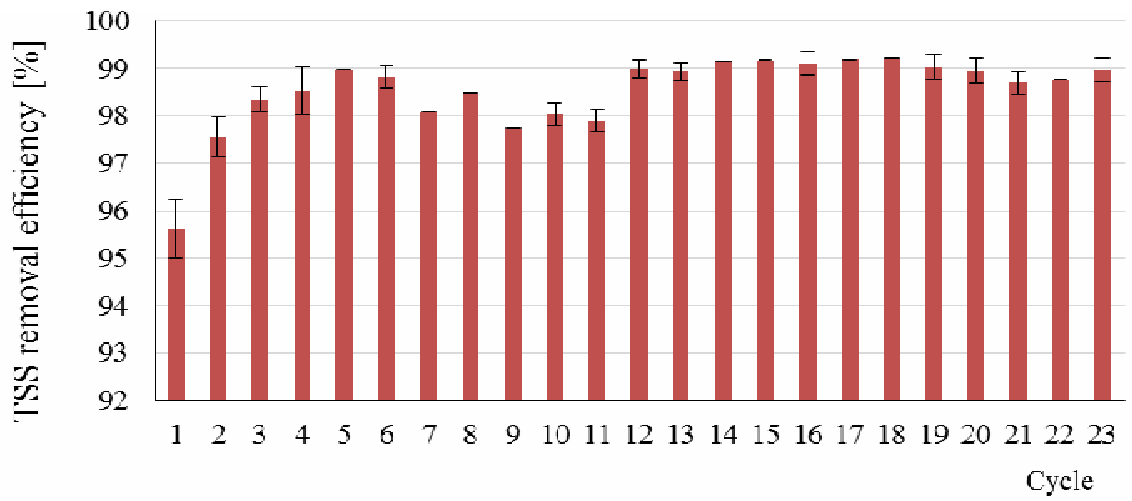

Fig. 2. TSS removal efficiency in the process of adaptation of the activated sludge in a SBR with standard deviation bars

The abundance of ciliates was controlled every two cycles. As can be seen from Figure 3 , the number of species declined substantially in the course of the experiment.
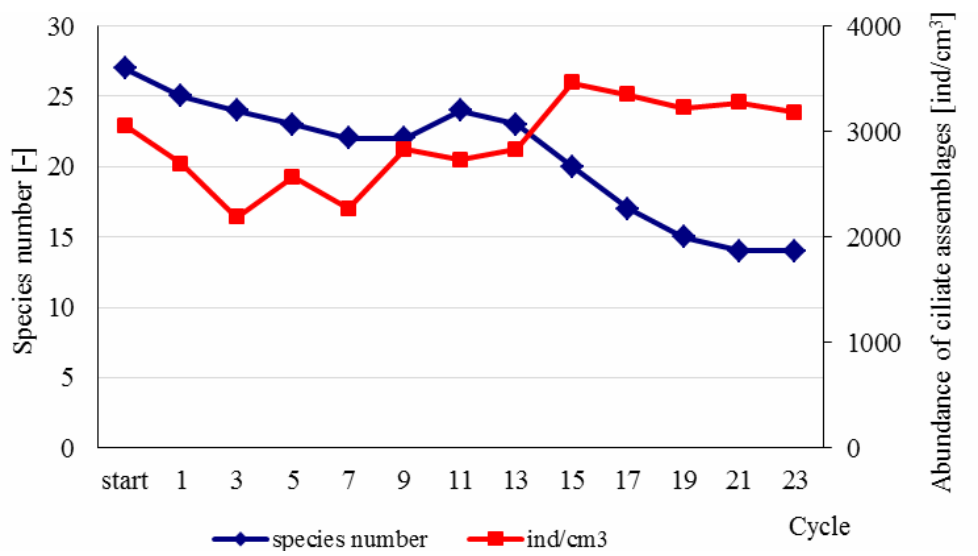

Fig. 3. The abundance of ciliate assemblages $\left[\mathrm{ind} / \mathrm{cm}^{3}\right]$ and their species number in the period of the experiment

The reduction of the species number was followed by an increase in their abundance starting from cycles 11-13.

Indexes calculated on the basis of abundance and species representation showed that the dominance increased together with the equalization decline (Fig. 4). Declining equalization and growing dominance were accompanied by a decrease in the overall diversity (Fig. 5), which is natural at significant reduction in the number of present species.

SBR technology is used all over the world successfully for big installations of Wastewater Treatment Plants (WWTP) or as a small laboratory installation. Undoubtedly, in order to solve the number of problems occurring during activated sludge studies, it is reasonable to conduct investigations in a laboratory scale. The transfer from the industrial to laboratory scale requires a period of adaptation of the activated sludge community to the 
conditions of the SBR $[19,20]$. The adaptation period should be neither too short, or else sludge will not be stabilized, nor too long, or else experiment will be time consuming. It is important to establish an average time required for the adaptation of activated sludge in the conditions of a laboratory SBR. The cluster analysis was used to study the structural rearrangements of the ciliate assembly during 23 cycles (Fig. 6).

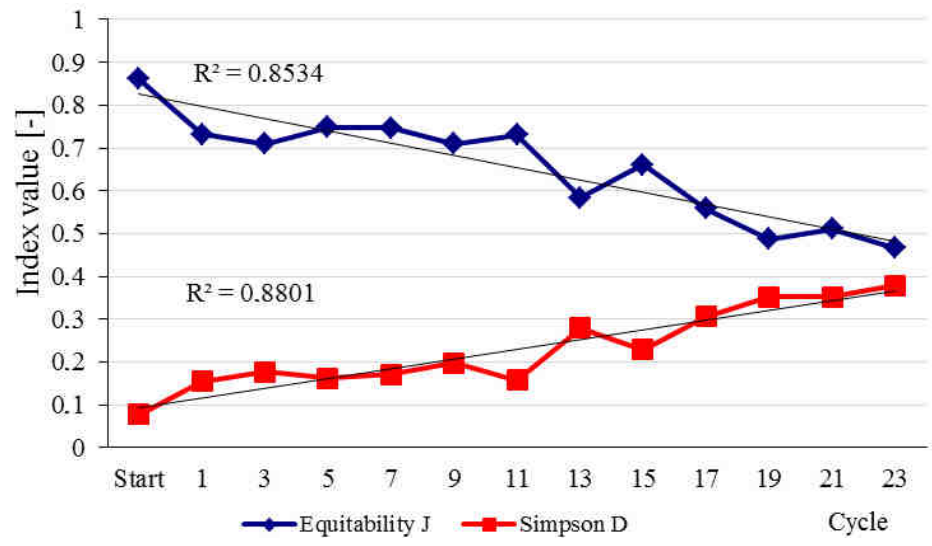

Fig. 4. The Simpson dominance index and equitability $(J)$ index calculated on the basis of the species composition of the ciliate assemblage

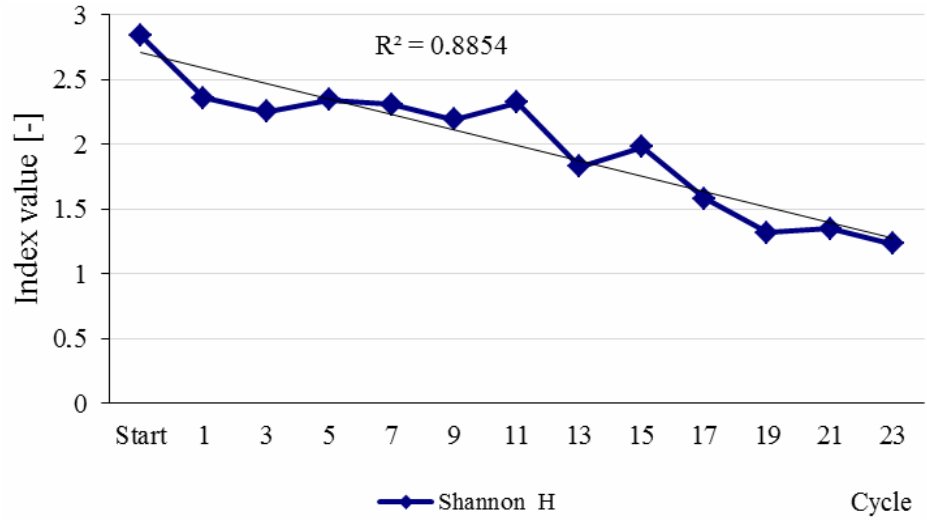

Fig. 5. The Shannon diversity index demonstrated the ciliate species diversity in the different subsequent cycles

The sample from the treatment plant demonstrates a specific independent structure. In the process of adaptation, the ciliate assembly split into two clusters. The first combined six cycles from 1 to 11 and the second - six cycles from 13 to 23 .

In the process of adaptation, there are two states of ciliate assembly to define - a transient period of an unstable structure and a stable period. The presence of the two periods during the experiment was also confirmed by other methods of analysis. Canonical correspondent analysis showed that the structure of ciliate assembly split into two states (Fig. 7). 


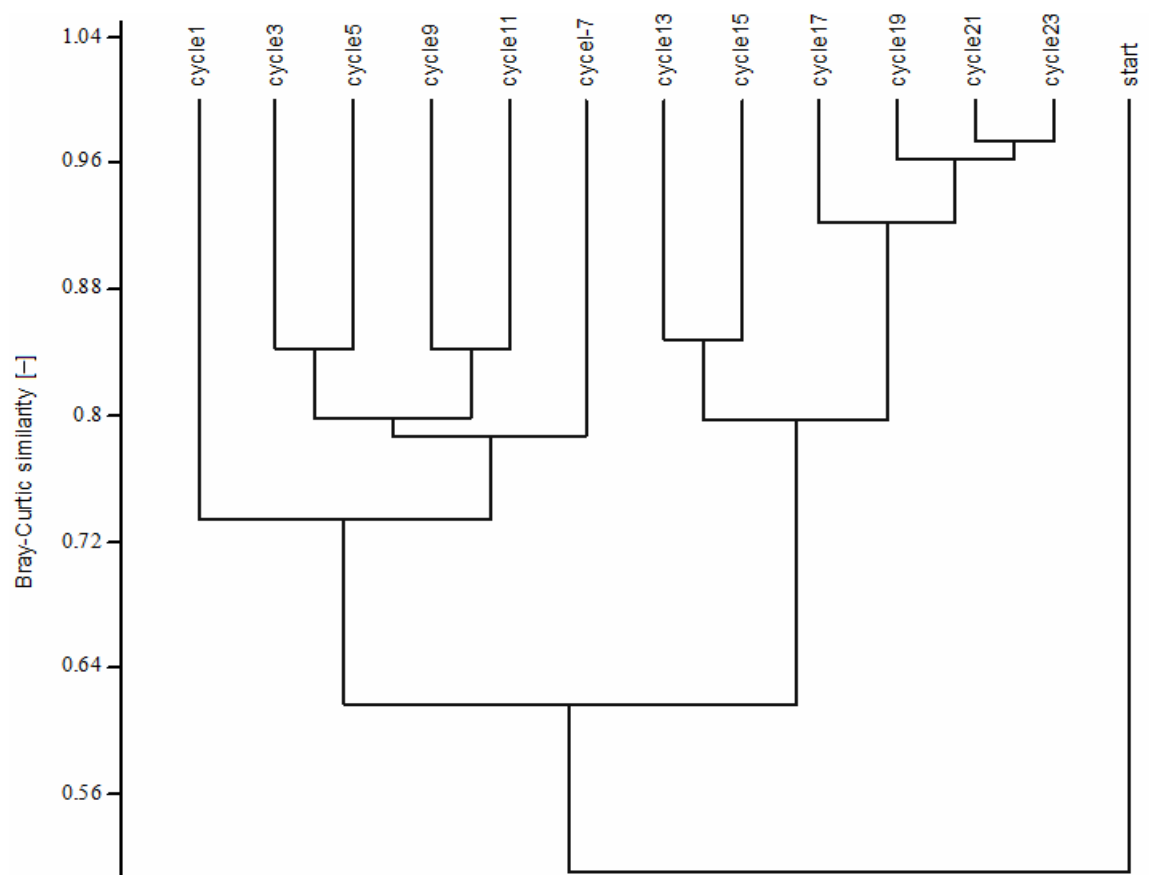

Fig. 6. The dendrogram of the 0 (start)-23 cycles calculated on the basis of the ciliate assemblage abundance, using the paired group linkage and Bray-Curtic similarity

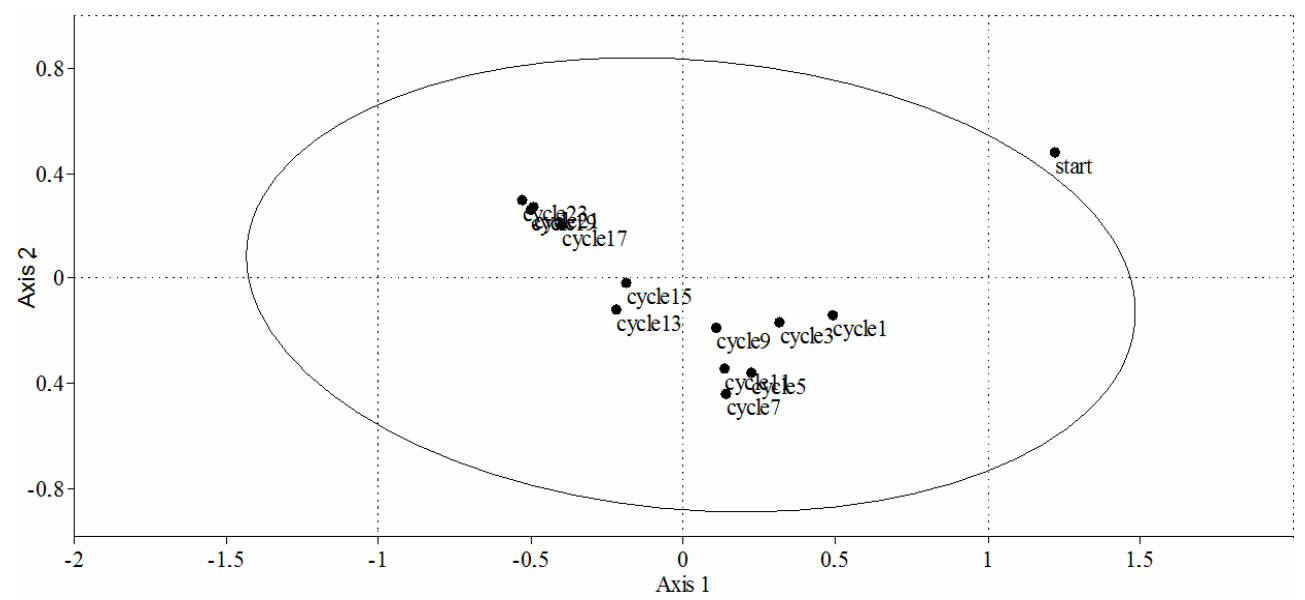

Fig. 7. CCA ordination diagram with the first two axes for the 0 (start)- 23 cycles data (environmental variables are not shown)

Moreover, between the transient period and adapted sludge, there is a state of transition, which lasts during cycles 13-15, ie two days. Hereby, the adapted sludge can be observed starting from cycle 17 , ie on the ninth day after the beginning of the adaptation process. 
Comparison of species diversity at the different stages of adaptation gave the following results.

Analysis of the protozoan structure with the method of rarefaction showed that the maximum potential number of species in a treatment plant at the moment of sampling was about 28 with total ciliate abundance 1000 ind./ $\mathrm{cm}^{3}$ (Fig. 8A). An increase in the number of expected species up to 30 at the same 1000 ind. $/ \mathrm{cm}^{3}$ was observed on the basis of the average values during the period of adaptation from cycle 1 to cycle 11 (Fig. 8B).
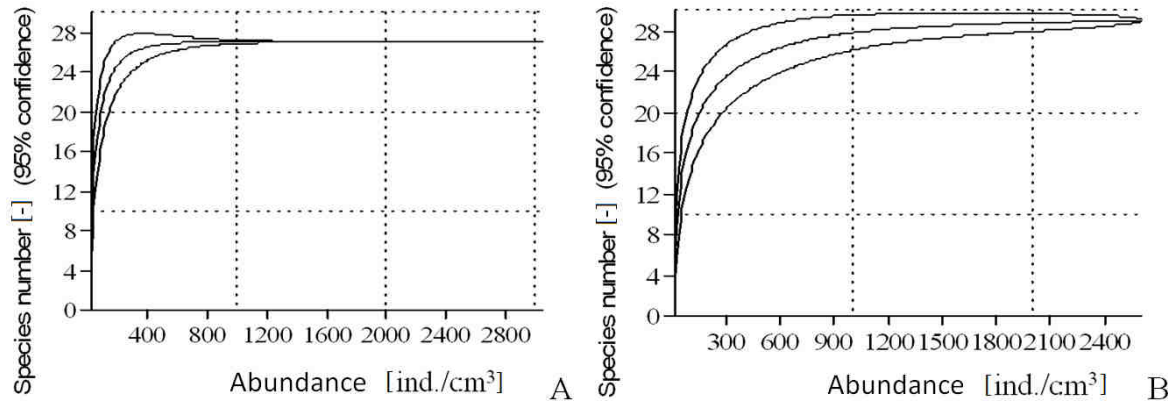

Fig. 8. The rarefaction curves show the potential number of species with $1000 \mathrm{ind} . / \mathrm{cm}^{3}$ ciliate abundance in the treatment plant at the moment of sampling (A); average values of ciliate abundance during the period of adaptation from cycle 1 to cycle 11 (B)

A possible reason is that the populations of the present species did not react to the emerging conditions for a new structure of the assembly and retained the same quantities that they had in the conditions of Hajdow.
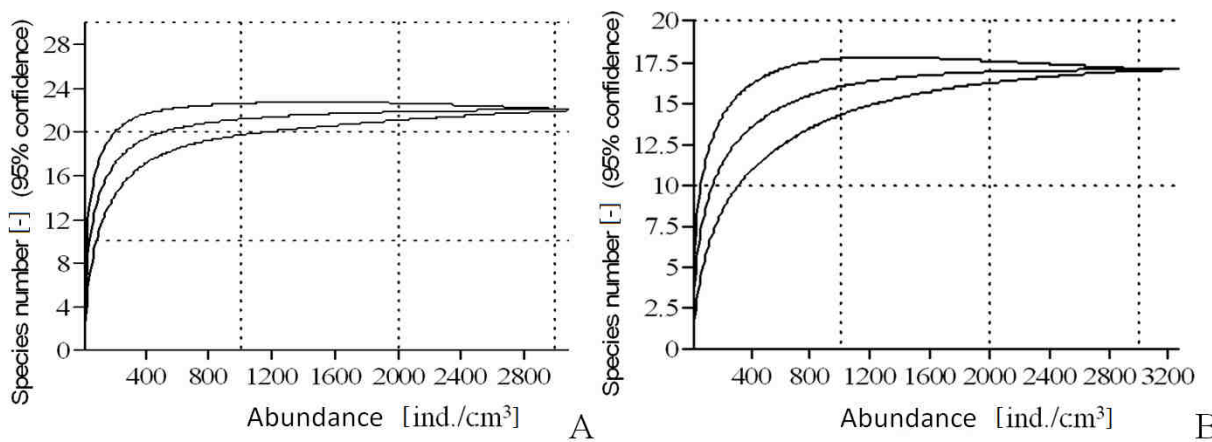

Fig. 9. The rarefaction curves show ciliate diversity during the period from cycle 13 to 15 at the abundance of 1000 ind.$/ \mathrm{cm}^{3}$ (A); the average values of ciliate abundance for the period of cycles $17-23(\mathrm{~B})$

As shown by the rarefaction curves, the ciliate diversity during the period from cycle 13 to 15 remained at the level of 20 at the abundance of 1000 ind./ $\mathrm{cm}^{3}$ (Fig. 9A).

Based on the average values of ciliate abundance for the period of cycles 17-23, the rarefaction curves showed diversity close to 15 species (Fig. 9B). 
Obviously, the process of activated sludge stabilization is accompanied by harmonization of the conditions, and the structure of ciliate assembly remains at the level of species diversity lower than the starting one.

Thus, it was observed that the protozoan assembly of activated sludge from the sewage treatment plant in the conditions of a small-volume SBR undergoes structural changes because of simplification, universalization, and unification of the living space and factorial determination that reduces the number of potential eco niches. This makes the structural reorganization of ciliate assemblies a significant criterion of activated sludge adaptation.

It is obvious that later, together with sludge ageing, its structure will undergo changes. This might be a subject of a further investigation of great interest.

\section{Conclusions}

- In the process of adaptation, reduction is observed in the number of ciliate species together with an increase in the total assembly abundance.

- A decrease in the Shannon index from 3 to 1 was observed.

- During the adaptation time, the equitability in the ciliate assembly falls and the dominance increases.

- On the basis of the structural changes in the assembly, it was demonstrated that the process was composed of two stages - a transient period and a stable period.

- The transient period lasted from 11 to 15 cycles.

- During the transient period, reduction of ammonium utilization efficiency down to $50 \%$ and its subsequent increase in the stable period up to $80 \%$ was observed.

- In the Hajdow wastewater treatment plant, a decrease in the ciliate species number from 28 to 15 in the stable period was observed during the adaptation process.

\section{Acknowledgments}

Research project partly financed from the budget for science in the years 2012-2013 within the "Diamond Grant" program. Grant no. 0013/DIA/2012/41.

The work was presented at International Scientific and Technical Conference Water Treatment Technologies - Technical, Biological and Ecological Aspects, Kyiv 3-5 December 2013.

\section{References}

[1] De Gregorio C, Caravelli AH, Zaritzky NE. Application of biological indices and a mathematical model for the detection of metal coagulant overload in a laboratory scale activated sludge reactor with phosphate simultaneous precipitation. Chem Eng J. 2011;172(1):52-60. DOI: 10.1016/j.cej.2011.05.063.

[2] Barton LE, Auffan M, Bertrand M, Barakat M, Santaella C, Masion A, et al. Transformation of pristine and citrate-functionalized $\mathrm{CeO} 2$ nanoparticles in a laboratory-scale activated sludge reactor. Environ Sci Technol. 2014;48(13):7289-7296. DOI: 10.1021/es404946y.

[3] Lim Y, Kim DJ. Quantification method of N2O emission from full-scale biological nutrient removal wastewater treatment plant by laboratory batch reactor analysis. Biores Technol. 2014;165:111-115. DOI: 10.1016/j.biortech.2014.03.021.

[4] Huang P, Li L, Kotay SM, Goel R. Carbon mass balance and microbial ecology in a laboratory scale reactor achieving simultaneous sludge reduction and nutrient removal. Water Res. 2014;53:153-167. DOI: 10.1016/j.watres.2013.12.035. 
[5] Barbusiński K. Adaptation of activated sludge to laboratory research conditions. Environ Protect Eng. 1991;17(3-4):57-65.

[6] Senthilnathan PR., Ganczarczyk JJ. Adaptation and deadaptation kinetics of activated sludge. Proc Indust Waste Conf. 1989;43:301-307.

[7] Ohtsuki T, Sakurai K, Noda S, Ichihara J, Masuda T, Ui S. Development of activated sludge adapted to high concentrations of phenol and enhancement of its phenol removal ability by addition of a processed lignite. Indian J Sci Technol. 2009;2(10):1-4.

[8] Thiem LT, Alkhatib EA. In situ adaptation of activated sludge by shock loading to enhance treatment of high ammonia content petrochemical wastewater. J Water Pollut Control Fed. 1988;60(7):1245-1252.

[9] Washington DR, Hetling LJ, Rao SS. Long-term adaptation of activated-sludge organisms to accumulated sludge mass. Symposium on Environmental Biochemistry. Biochem J. 1972;126(1):35.

[10] Boonnorat J, Chiemchaisri C, Chiemchaisri W, Yamamoto K. Microbial adaptation to biodegrade toxic organic micro-pollutants in membrane bioreactor using different sludge sources. Biores Technol. 2014;65:50-59. DOI: 10.1016/j.biortech.2014.04.024.

[11] Orozco AMF, Lobo CC, Contreras EM, Zaritzky NE. Biodegradation of bisphenol-A (BPA) in activated sludge batch reactors: Analysis of the acclimation process. Internat Biodeter Biodegrad. 2013;85:392-399. DOI: 10.1016/j.ibiod.2013.09.005.

[12] Van Dierdonck J, Van den Broeck R, Vervoort E, Van Impe J, Smets I. The effect of alternating influent carbon source composition on activated sludge bioflocculation. J Biotechnol. 2013;167(3):225-234. DOI: 10.1016/j.jbiotec.2013.07.012.

[13] Xu S, Zhang Y, Sims A, Bernards M, Hu Z. Fate and toxicity of melamine in activated sludge treatment systems after a long-term sludge adaptation. Water Res. 2013;47(7):2307-2314. DOI: 10.1016/j.watres.2013.01.048.

[14] De Gregorio C, Caravelli A, Zaritzky N. Application of a combined biological and chemical system for the treatment of phosphorus-containing wastewater from the food industry. Proc Food Sci. 2011;1:1841-1847. DOI: 10.1016/j.profoo.2011.09.270.

[15] Sabliy L, Kuzminskiy Y, Gvozdyak P, Łagód G. Anaerobic and aerobic treatment of wastewater of milk plants. Proc ECOpole. 2009;3(2):373-378.

[16] Gryta A, Frąc M, Oszust K. The application of the Biolog EcoPlate approach in ecotoxicological evaluation of dairy sewage sludge. Appl Biochem Biotechnol. 2014 (in print). DOI 10.1007/s12010-014-1131-8.

[17] Bazhenov VI., Kanunnikova MA. The mechanism of activated sludge adaptation to low concentrations of oxygen. Dostizenia Nauki Tehn APK. 2012;9:82-84.

[18] Anielak A, Piaskowski K. Badania laboratoryjne oczyszczania ścieków osadem czynnym z zastosowaniem zeolitu i PIX-u. Rocz Ochr Środow./Ann Set Environ Protect. 2000;2:281-295.

[19] Van den Kerkhof P, Gins G, Van den Broeck R, Van Impe JFM. Multivariate assessment of activated sludge stability in lab-scale experiments. Process Biochem. 2013;48(11):1789-1793. DOI: 10.1016/j.procbio.2013.07.016.

[20] Van den Broeck R, Van Impe JFM., Smets IYM. Assessment of activated sludge stability in lab-scale experiments. J Biotechnol. 2009;141(3-4):147-154. DOI: 10.1016/j.jbiotec.2009.02.019.

[21] Li XY, Yang SF. Influence of loosely bound extracellular polymeric substances (EPS) on the flocculation, sedimentation and dewaterability of activated sludge. Water Res. 2007;41(5):1022-1030. DOI: 10.1016/j.watres.2006.06.037.

[22] Masse A, Sperandio M, Cabassud C. Comparison of sludge characteristics and performance of a submerged membrance bioreactor and an activated sludge process at high solids retention time. Water Res. 2006;40(12):2405-2415. DOI: 10.1016/j.watres.2006.04.015.

[23] Agridiotis V, Forster CF, Cartiell-Marquet C. Addition of Al and Fe salts during treatment of paper mill effluents to improve activated sludge settlement characteristics. Biores Technol. 2007;98(15):2926-2934 . DOI: $10.1016 /$ j.biortech.2006.10.004.

[24] Mendrycka M, Stawarz M. Possibilities of applications of biocomponent for biological processes of tanning sewage by activated sludge-aided method. Inż Ekol. 2012;28:43-56.

[25] Curds CR. A theoretical study of factors influencing the microbial population dynamics of the activated sludge process - I The effects of diurnal variations of sewage and carnivorous ciliated protozoa. Water Res. 1973;7(9):1269-1284. DOI: 10.1016/0043-1354(73)90004-3.

[26] Martín-Cereceda M, Pérez-Uz B, Serrano S, Guinea A. Dynamics of protozoan and metazoan communities in a full scale wastewater treatment plant by rotating biological contactors. Microbiol Res. 2001;156(3):225-238. DOI: 10.1078/0944-5013-00105. 
[27] Zhou K, Xu M, Liu B, Cao H. Characteristics of microfauna and their relationships with the performance of an activated sludge plant in China. J Environ Sci. 2008;20(4):482-486. DOI: 10.1016/S1001-0742(08)62083-5.

[28] Tsang YF, Hua FL, Chua H, Sin SN, Wang YJ. Optimization of biological treatment of paper mill effluent in a sequencing batch reactor. Biochem Eng J. 2007;34(3):193-199. DOI: 10.1016/j.bej.2006.12.004.

[29] Jenne R, Cenens C, Geeraerd AH, Van Impe JF. Towards on-line quantification of flocs and filaments by image analysis. Biotechnol Lett. 2002;24(11):931-935. DOI: 10.1023/A:1015512712843.

[30] Jenne R, Banadda EN, Smets IY, Deurinck J, Van Impe JF. Detection of filamentous bulking problems: developing an image analysis system for sludge composition monitoring. Microsco Microanal. 2007;13(1):36-41. DOI: 10.1017/S1431927607070092.

[31] Łagód G, Chomczyńska M, Montusiewicz A, Malicki J, Bieganowski A. Proposal of measurement and visualization methods for dominance structures in the saprobe communities. Ecol Chem Eng S. 2009;16(3):369-377.

[32] Hammer O, Harper DAT, Ryan PD. PAST: Paleontological statistics software package for education and data analysis. Paleon Electro. 2001;4(1):1-9.

[33] Shannon CE, Weaver W. The Mathematical Theory of Communication. Chicago: University of Illinois Press, Urbana; 1949, reprint 1998.

[34] Gove IH, Patil GP, Swindel BF, Taille C. Ecological diversity and forest management. Handbook of Statistic 12. Patil GP, Rao CR, editors. Amsterdam, London, New York, Tokyo: Elsevier Sci; 1994;12:409-462. DOI: $10.1016 / \mathrm{S} 0169-7161(05) 80014-8$.

[35] Washington HG. Diversity, biotic and similarity indices: a review with special relevance to aquatic ecosystems. Water Res. 1984;18(6):653-694. DOI: 10.1016/0043-1354(84)90164-7.

[36] Magurran AE. Ecological Diversity and its Measurements. Princeton: Princeton University Press; 1988.

[37] Chomczyńska M, Montusiewicz A, Malicki J, Łagód G. Application of saprobes for bioindication of wastewater quality. Environ Eng Sci. 2009;26(2):289-295. DOI: 10.1089/ees.2007.0311.

[38] Kim DJ, Lee DI, Keller J. Effect of temperature and free ammonia on nitrification and nitrite accumulation in landfill leachate and analysis of its nitrifying bacterial community by FISH. Biores Technol. 2006;97(3):459-468. DOI: 10.1016/j.biortech.2005.03.032.

[39] Babko R, Łagód G, Jaromin-Gleń KM. Abundance and structure of ciliated protozoa community at the particular devices of "Hajdów" WWTP. Ann Set Environ Protect. 2012;14:56-68.

[40] Jaromin-Gleń K, Babko R, Łagód G, Sobczuk H. Community composition and abundance of protozoa under different concentration of nitrogen compounds at "Hajdow" wastewater treatment plant. Ecol Chem Eng S. 2013;20(1):127-139. DOI: 10.2478/eces-2013-0010.

[41] Rasool K, Ahn DH, Lee DS. Simultaneous organic carbon and nitrogen removal in an anoxic-oxic activated sludge system under various operating conditions. Bioresour Technol. 2014;162:373-378. DOI: 10.1016/j.biortech.2014.03.108.

\title{
BIOINDYKACYJNA OCENA ADAPTACJI OSADU CZYNNEGO W WARUNKACH EKSPERYMENTU LABORATORYJNEGO
}

\author{
${ }^{1}$ Instytut Zoologii im. I.I. Schmalhausena, Narodowa Akademia Nauk Ukrainy, Kijów, Ukraina \\ ${ }^{2}$ Państwowy Uniwersytet Sumski, Sumy, Ukraina \\ ${ }^{3}$ Instytut Agrofizyki im. Bohdana Dobrzańskiego, Polska Akademia Nauk, Lublin
}

\begin{abstract}
Abstrakt: Zaprezentowano badania dotyczące procesu adaptacji osadu czynnego pobranego w miejskiej oczyszczalni ścieków Hajdów (Lublin, Polska) do warunków pracy w laboratoryjnym bioreaktorze typu SBR. Jako kryterium wspomnianej adaptacji (wpracowania) przyjęto parametry struktury zbiorowiska orzęsków osadu czynnego. Podczas eksperymentu w analizowanym osadzie czynnym zidentyfikowano 32 gatunki orzęsków, zaś bazując na ich liczebności, analizowano zmiany następujące w strukturze zbiorowiska w kolejnych etapach badań. Podczas etapu adaptacji obserwowano redukcję liczby gatunków następującą równocześnie ze wzrostem liczebności całego zbiorowiska orzęsków, stąd też w kolejnych dniach widoczny był spadek wartości indeksu różnorodności Shannona i indeksu równomierności. Podczas adaptacji osadu zaobserwowano wyraźne rozgraniczenie struktury zbiorowiska orzęsków - niestabilnej etapu przejściowego oraz struktury stabilnej. W trakcie okresu przejściowego adaptacji zaobserwowano także znaczny spadek efektywności usuwania azotu amonowego - do poziomu $50 \%$, a potem jej sukcesywny wzrost do stabilnego poziomu $80 \%$. W pierwszym ze wspomnianych etapów indeks dominacji Simpsona przyjmował niskie wartości, natomiast w drugim wyraźnie
\end{abstract}


wzrastał. Dla temperatury $10^{\circ} \mathrm{C}$ okres przejściowy trwał od sześciu do dziewięciu dni, po tym okresie zbiorowisko orzęsków osadu czynnego cechowało się obniżonym poziomem różnorodności. Opracowanie danych za pomocą metody rarefakcji wykazało, że w trakcie okresu adaptacji osadu czynnego do warunków pracy w bioreaktorze laboratoryjnym liczba potencjalnych niszy ekologicznych dla orzęsków osiągała poziom 30, natomiast dla osadu o stabilnej strukturze po okresie adaptacji poziom z zakresu 15-20.

Słowa kluczowe: bioindykacja, osad czynny, zbiorowiska orzęsków, indeksy biocenotyczne, adaptacja, bioreaktor typu SBR, eksperyment laboratoryjny 